\title{
The Effect of Adolescents' Reading Children's Literature to Their Younger Siblings on Their Book Reading Habits
}

\author{
Miray Özözen Danacı ${ }^{1}$, Zeynep Çetin², Özcan Doğan² \\ ${ }^{1}$ Department of Child Development, Duzce University, Duzce, Turkey \\ ${ }^{2}$ Faculty of Healty Sciences, Hacettepe University, Ankara, Turkey \\ Email: mirayozozen@hotmail.com, zcetin@hacettepe.edu.tr, ozcdogan@hacettepe.edu.tr
}

Received 9 September 2015; accepted 27 October 2015; published 30 October 2015

Copyright (C) 2015 by authors and Scientific Research Publishing Inc.

This work is licensed under the Creative Commons Attribution International License (CC BY). http://creativecommons.org/licenses/by/4.0/

(c) (i) Open Access

\begin{abstract}
The purpose of this study is to evaluate the effect of children's reading activities carried out by adolescents for their siblings on their reading habits. The study is an experimental study with a pretest-posttest model and experimental and control groups. Its sample included 56 adolescents aged 15-16 with siblings aged 4-5 in kindergarten (n: 56). As the pretest and posttest, Gomleksiz's Attitude Scale on Book Reading Habituation (2004) was used. After the pretest, adolescents read to their younger siblings 2 days a week for 25 minutes during a 14-week period. The posttest data collected were examined, and no statistically significant difference was found between the experimental and control groups. These results indicate that adolescents reading for their siblings may support their potential for book reading habituation, but this practice alone is insufficient.
\end{abstract}

\section{Keywords}

Children's Literature, Habituation, Reading, Attitude, Activity

\section{Introduction}

In our age of science and technology, reading is one of the most important habits that one can acquire. For this reason, children should be introduced to books as soon as possible. Literature enables children to see the world from other perspectives and help their imagination expand by transporting them to other places and exposing them to the lives of others. Reading, not only consists the substructure of taking information but also constitutes the basis of critical thought, interpretationing force (Ungan, 2008). Experiences at early ages are crucial for de- 
veloping good reading habits (Huck et al., 2003; Hunt, 1996).

Can a relationship be established among children, literature, and reading habits? Reading is a complex cognitive process which is realized by combining many functions like seeing, perceiving, vocalizing, comprehending, and constructing in the brain (Balci, et al., 2012; Bamberger, 1990). Literature has a place in the worlds of children primarily due to its entertaining and relaxing functions. Lullabies and melodies heard from the mother and other elders are the first kind of literature that children encounter (Kuran, 2009). Literature "includes products that are appropriate for early childhood and adolescence and assist with children's linguistic development and levels of comprehension. It also enriches their worlds of emotion and thought with linguistic and visual messages and increases their level of enjoyment” (Sever, 2004). Literature depicts characters and events with which the children can identify their own acts, beliefs, and emotions (Mendoza \& Reese, 2001). The books read by adolescents and those read to children are effective from a psycho-social perspective when they build new opinions based on knowledge of the environment and allow that knowledge to be internalized along with older knowledge (Elliker, 2005).

Love and interest in reading are the first step toward acquiring good reading habits. In our developing country, young people's reading habits are among the leading research fields for creating a more conscious and developed society (Gonen et al., 2004).

Books that have linguistic, literary, artistic, and aesthetic values and aim at cultivating good readers and caring individuals are the most effective ways for children to be encouraged to engage in the processes of listening, reading, writing, thinking, and acquiring a culture of criticism (Sirin, 2007). Especially in poststructuralist analyses of children's literature and its reading processes, the influence of this and other aspects of the romantic paradigm becomes obvious (Joosen \& Vloeberghs, 2006).

Adolescence is an important time when physical and emotional changes occur. It should also be perceived as a period of cognitive development as well as social, emotional and interpersonal change. Along with growth and development, adolescents are influenced primarily by friends and family as well as by external factors such as the society, culture, religion, school, global events and the media. This is time consuming for them, and reading ends up on the back burner (Degirmencioglu, Urber, Tolson, \& Richard, 1998). In having the habit of reading, individual's family have the first role, and then their community, school and teacher (Gurcan, 1999). For this reason, as required by the developmental characteristics of adolescents, they must be enabled to realize that reading is a fun component of their healthy individual development (Calkins, 2001; Stanovich, 2000).

Researches evidence suggests that family environments constitute the basic ecology where children's behavior is manifested, learned, encouraged, and suppressed (Santora, 2013; Dishion \& Patterson, 2006). The empirical researches have been published in the last decade that directly addressed the effectiveness of counseling for adolescents through a family member (Hoskins, 2014; Criss, et al., 2013; Dalton \& Krout, 2005; Layne et al., 2001; Rotheram-Borus, Stein \& Lin, 2001; Christ et al., 2003; Sandler et al., 2003). Reading preparation is a circuit that allows child to learn reading with relish and easily (Gray, 1975). Parents' roles in the family environment have primarily been to prepare children for adulthood with rules and corrections. Behavioral interaction between infants and primary caregivers leads to mental representations of attachment relationships formed in infancy and forming basis of adolescence. Especially during adolescence, the influence of peers also serves as an important socialization agent. Research has clearly indicated that parenting and sibling accounts for more variance in externalizing behaviors in adolescence than any other one factor (Crosswhite, Kerpelman, \& Coercion, 2009; Dekovic, Janssens, \& As, 2003; Bartle-Haring et al., 2002; Bowlby, 1969). In fact, much of the research on children's sibling relationships has focused on how interactions with brothers and sisters provide children with opportunities to learn new skills and behaviours (Brody, 1998). At present, most of the information on sibling experiences has come from younger children's relationships so that more recently, researchers have begun to focus on sibling relationships in adolescence especially in family interaction and education guiding (Stocker \& Dunn, 1994; Tucker, Barber, \& Eccles, 1997; Bryant \& Crockenberg, 1980).

In these interactions, siblings are the more expressing role and increase in relations with subjects. But most of the studies on family relationships focus on parent-adolescent relationships, the few that analyse sibling relationships find that changes in such relationships are characterized by increased conflicts during early adolescence (Oliva \& Arranz, 2005; Alleyne et al., 2005; Brody, Stoneman, \& McCoy, 1994; Cole, 1996).

The sibling relationships of adolescents also go through changes. Adolescents may feel responsible for protecting their siblings, especially in social-emotional grounds, providing guidance and offering suggestions (Tucker, Barber, \& Eccles, 1997). When adolescents experience such emotions, they can learn to improve their 
self-confidence and realize their own interests. Adolescents' positive sibling relationships are said to influence the social adaptability of adolescents and children (Barber, Olsen, \& Shagle, 1994; Seginer, 1998). Some researches put forward that sibling interactions were associated with good degrees of personal progress, and that the influence of siblings may be even greater and qualified than that exerted by parents (Yeh, 2004, Oliva \& Arranz, 2005). According to their environmental conditions individuals are encouraged or inhibited to the habit of reading (Odabas, 2008). Thus, adolescents might positively influence their own reading habits by reading for their siblings, informing them, guiding them, and experiencing the contentedness this relationship gives them.

\section{Methodology}

\subsection{Participants}

This research examines the effect of children's reading activities carried out by adolescents for their siblings on their reading habits. The research sample included 56 adolescents (that were secondary school students) aged 15 16 with siblings aged 4 - 5 in kindergarten (n: 56). This is an experimental study and it divided the participants into an experimental and a control group. Both groups did the pretest and the posttest, but the experimental group also participated in an educational program prior to the posttest.

\subsection{Data Collection and Analysis}

Prior to the experiment, the adolescents were informed by experts at seminars in kindergartens about children's literature (fairy tales, novels and stories, picture books, finger games, riddles and nursery rhymes) and about story telling methods and processes (computers, flannel boards, puppet shows, shadow shows, flip charts, story cards, and narration). Examples were shared, and on the same day each adolescent was asked to do a one preliminary activity for 20 minutes under the supervision of an expert.

First, the 30-item book reading habituation attitude scale developed by Gomleksiz (2004) was administered to the experimental and the control group. The scale's validity and reliability tests have been conducted. It includes these sub-dimensions: love, reading habits, requirements, desire, effect, and benefit. A survey of demographic information developed by researchers was also administered to both groups along with a survey about their issues with reading books (buying books, library and bookstore name, book reading rates). After the pretest, the adolescents did children's literature activities for 14 weeks, 2 days a week and for 25 minutes a day. The posttest was administered to the experimental group and control group after these activities.

\section{Results}

Table 1 shows that the pretest book reading habituation attitude score of the experimental group is 121.03 and 122.57 for the control group. The control group has higher level of book reading habituation, yet according to the results of the $t$ test, there is no statistically significant difference between the two groups $[t=1.22,0.427 ; p>$ 0.05]. Therefore, the groups were initially found to have equivalent book reading habituation attitudes.

Table 2 shows that the total score of the experimental group on the reading habituation attitude scale was $121.03 \pm$ 8.56 prior to the children's literature activities, and that afterwards their total score increased to $132.51 \pm 10.32$. Yet the difference between pretest and posttest score averages is not statistically significant $(\mathrm{t}=-1.92, p<0.05)$.

When the book reading habituation attitude scale's sub-dimensions of love, habituation, requirement, desire, benefit, and effect are examined, the children's literature activities increased the posttest attitude scores of experimental group to some extent; however, this increase was not found to be significant. The t-test found the highest increase in the sub-dimension of benefit. The literary activities of the adolescents did not affect their reading habits. This can be understood as a consequence of the fact that their literary education has not been effective.

Ucgun (2010) stated that children's literature course hours were insufficient, despite practical exercise requirements. Buyukkavas, Kuran, \& Ersozlu (2009) and Maltepe (2009) argued that, not only theoretical progress, but practice is also necessary. Ozkan \& Sahbaz (2011) attracted attention to the incoherent and insufficient theoretical practices in the Turkish language courses taught by Turkish teacher candidates.

Table 3 shows the t-test analysis of the in-group variables for the scores of the experimental group and control group score averages posttest numerical data. According to the results, an increase was observed in the posttest score averages of the experimental group. The posttest score averages of the control group, who did not do any children's literature activities, were lower than those of the experimental group and remained at similar 
Table 1. T-test results for the pretest scores of the experimental and control groups.

\begin{tabular}{|c|c|c|c|c|c|c|}
\hline Test & Groups & $\mathbf{N}$ & $\mathbf{X}$ & sd & t & $\mathbf{P}$ \\
\hline \multirow{2}{*}{ Pre-Test } & Experimental & 56 & 121.03 & 0.94 & \multirow{2}{*}{1.22} & \multirow{2}{*}{0.427} \\
\hline & Control & 56 & 122.57 & 1.02 & & \\
\hline
\end{tabular}

${ }^{*} p<0.01$.

Table 2. Descriptive statistics for the pretest and posttest scores of the control group with t-test about reading book habituation attitude.

\begin{tabular}{|c|c|c|c|c|c|c|c|}
\hline $\begin{array}{c}\text { Reading Book } \\
\text { Habituation Attitude Scale }\end{array}$ & Tests & $\mathbf{N}$ & df & $\mathbf{X}$ & sd & $\mathbf{t}$ & $\mathbf{P}$ \\
\hline Sum of Scale & $\begin{array}{l}\text { Pre Test } \\
\text { Post Test }\end{array}$ & 56 & & $\begin{array}{l}121.03 \\
132.51\end{array}$ & $\begin{array}{c}8.56 \\
10.32\end{array}$ & -1.92 & $\begin{array}{l}P>0.05 \\
P<0.01\end{array}$ \\
\hline Reading Habits & $\begin{array}{l}\text { Pre Test } \\
\text { Post Test }\end{array}$ & 56 & $\begin{array}{l}2.46 \\
2.87\end{array}$ & $\begin{array}{l}14.76 \\
16.02\end{array}$ & 2.17 & 2.17 & $\begin{array}{l}P>0.05 \\
P<0.01\end{array}$ \\
\hline Love & $\begin{array}{l}\text { Pre Test } \\
\text { Post Test }\end{array}$ & 56 & $\begin{array}{l}3.73 \\
3.92\end{array}$ & $\begin{array}{l}26.11 \\
27.59\end{array}$ & 3.45 & -1.40 & $\begin{array}{l}P>0.05 \\
P<0.01\end{array}$ \\
\hline Desire & $\begin{array}{l}\text { Pre Test } \\
\text { Post Test }\end{array}$ & 56 & $\begin{array}{l}3.91 \\
3.98\end{array}$ & $\begin{array}{l}13.02 \\
12.97\end{array}$ & 2.16 & 2.05 & $\begin{array}{l}P>0.05 \\
P<0.01\end{array}$ \\
\hline Benefit & $\begin{array}{l}\text { Pre Test } \\
\text { Post Test }\end{array}$ & 56 & $\begin{array}{l}3.04 \\
3.86\end{array}$ & $\begin{array}{l}41.71 \\
43.64\end{array}$ & 3.98 & 3.98 & $\begin{array}{l}P>0.05 \\
P<0.01\end{array}$ \\
\hline Requirement & $\begin{array}{l}\text { Pre Test } \\
\text { Post Test }\end{array}$ & 56 & $\begin{array}{l}2.05 \\
2.74\end{array}$ & $\begin{array}{l}10.06 \\
10.88\end{array}$ & 1.87 & 1.75 & $\begin{array}{l}P>0.05 \\
P<0.01\end{array}$ \\
\hline Effect & $\begin{array}{l}\text { Pre Test } \\
\text { Post Test }\end{array}$ & 56 & $\begin{array}{l}1.42 \\
1.78\end{array}$ & $\begin{array}{l}17.60 \\
18.92\end{array}$ & 1.94 & 1.95 & $\begin{array}{l}P>0.05 \\
P<0.01\end{array}$ \\
\hline
\end{tabular}

Table 3. The book reading habituation attitude scale posttest scores of the experimental and control groups.

\begin{tabular}{cccccc}
\hline Test & Groups & N & X & sd & t \\
\hline \multirow{2}{*}{ Post Test } & Experimental & 56 & 132.51 & 1.07 & 1.26 \\
& Control & 56 & 124.05 & 1.32 & 0.123 \\
\hline
\end{tabular}

${ }^{*} p<0.05$

levels to their pretest scores $(p<0.05)$. The difference between the posttest scores of experimental and control groups was not found to be statistically significant $(p<0.05)$. Thus, despite the positive indicators for reading habits in the experimental group, the children's literature activities did not significantly affect their reading habits.

Newbery (1765) and some other thinkers influenced by Newbery’s work focused on adolescents rather than the children in the children's stories they wrote. They found that adults and adolescents defined the books they examined as unliterary, which was regarded as a deficiency by them. In their study, Gungor (2009), Stahlschmidt \& Agnes (1981) mentioned two important factors regarding the improvement of people’s children’s literature reading habits. These factors are families and teachers. Yet in order for these positive impacts to emerge, dynamic and continuous book reading activities are necessary. Clark \& Rumnold (2006) also argued that teachers are the most important figures in the development of reading habituation.

According to Table 4, male adolescents have a higher reading habituation attitude score than females; however, the difference between males and females was not found to be significant at the $\mathrm{P}<0.01$ level. When the data is examined, it shows that positive effects were more distinguishable in males.

Table 5 also shows that there is a clearly observed increase in adolescents' rates of book purchases and acquaintance with the names of libraries and bookstores. As the table shows, there is some increase in the experimental group's book purchases, acquaintance with the names of books and going to bookstores. In the control group there was no such increase, and some frequency values of the control group are lower. This program 
showed that reading children's literature improves the reading attitudes of adolescents.

In interviews, the adolescents who read to their siblings said that they have more positive views on reading habituation than the adolescents who did not do so. They also said that reading to their siblings had numerous effects on them personally. Thus reading children's literature changed their opinions about reading: "I think children's literature is so amusing, and I bought a new novel since then" (E, 15, M); "I think my sister learned so much using puppets and story cards.” (H, 16, E); "Actually, reading is so beneficial and enjoyable” (A, 15, F); "I didn’t use to be able to find spare time to read at all, but now I can find time to read” (M, 16, F).

Table 4. The book reading habituation of adolescents by gender.

\begin{tabular}{cccccccc}
\hline Reading Book Habituation Scale & Tests & $\mathbf{n}$ & $\mathbf{d f}$ & $\mathbf{X}$ & sd & $\mathbf{t}$ & $\mathbf{P}$ \\
\hline \multirow{2}{*}{ Female } & Pre-test & 28 & & 26.75 & 14 & -3.13 & 0.672 \\
& Post -test & & 27.55 & & & 0.672 \\
Male & Pre-test & & 28 & 30.83 & 14 & -2.75 & \\
\hline
\end{tabular}

${ }^{*} p<0.01$.

Table 5. Frequency results regarding reading habituation according to interview data.

\begin{tabular}{|c|c|c|c|c|c|c|c|}
\hline & & Gender & $\begin{array}{l}\text { Reading book } \\
\text { (Per week) }\end{array}$ & $\begin{array}{l}\text { Reading book } \\
\text { (Per Month) }\end{array}$ & $\begin{array}{l}\text { Standing book } \\
\text { (Per week) }\end{array}$ & $\begin{array}{l}\text { Standing book } \\
\text { (Per Month) }\end{array}$ & $\begin{array}{l}\text { Following } \\
\text { bookshop }\end{array}$ \\
\hline & & & F & $\mathrm{F}$ & $\mathrm{F}$ & $\mathrm{F}$ & $\mathrm{F}$ \\
\hline \multirow{8}{*}{$\begin{array}{l}\text { Experimental } \\
\text { Group }\end{array}$} & \multirow{3}{*}{$\begin{array}{c}\text { Before } \\
\text { Program }\end{array}$} & Female & 0.89 & 3.57 & 0.97 & 3.75 & 2.05 \\
\hline & & Male & 0.92 & 3.75 & 0.94 & 3.83 & 1.78 \\
\hline & & Total & 0.90 & 3.66 & 0.95 & 3.79 & 1.91 \\
\hline & \multirow{3}{*}{$\begin{array}{c}\text { After } \\
\text { Program }\end{array}$} & Female & 1.23 & 3.78 & 1.42 & 3.92 & 5.10 \\
\hline & & Male & 1.33 & 3.98 & 1.57 & 4.14 & 5.35 \\
\hline & & Total & 1.28 & 3.88 & 1.49 & 4.03 & 5.22 \\
\hline & & Gender & $\begin{array}{l}\text { Reading book } \\
\text { (Per a week) }\end{array}$ & $\begin{array}{l}\text { Reading book } \\
\text { (Per a Month) }\end{array}$ & $\begin{array}{l}\text { Standing book } \\
\text { (Per a week) }\end{array}$ & $\begin{array}{l}\text { Standing book } \\
\text { (Per a Month) }\end{array}$ & $\begin{array}{l}\text { Following } \\
\text { bookshop }\end{array}$ \\
\hline & & & $\mathrm{F}$ & $\mathrm{F}$ & $\mathrm{F}$ & $\mathrm{F}$ & $\mathrm{F}$ \\
\hline \multirow{6}{*}{$\begin{array}{l}\text { Control } \\
\text { Group }\end{array}$} & \multirow{3}{*}{$\begin{array}{c}\text { Before } \\
\text { Program }\end{array}$} & Female & 0.89 & 3.56 & 0.98 & 3.67 & 2.03 \\
\hline & & Male & 0.92 & 3.74 & 0.93 & 3.87 & 1.73 \\
\hline & & Total & 0.90 & 3.65 & 0.94 & 3.77 & 1.88 \\
\hline & \multirow{3}{*}{$\begin{array}{c}\text { After } \\
\text { Program }\end{array}$} & Female & 0.75 & 1.73 & 1.05 & 3.65 & 1.71 \\
\hline & & Male & 0.33 & 1.78 & 0.91 & 3.73 & 1.76 \\
\hline & & Total & 0.54 & 1.75 & 0.98 & 3.69 & 1.73 \\
\hline
\end{tabular}

\section{Conclusion}

This study found that the reading habits of adolescents were improved to some extent by the children's literature activities they performed for their younger siblings, but the difference between their pretest and posttest scores was not statistically significant. Here are some things that teachers should do to improve adolescents' reading habits:

1) Rather than giving homework and exercises based only on individual in-class book reading activities, teachers should assign the adolescents long-term tasks that can be fulfilled by interacting with their siblings.

2) Teachers should consider the social and interactive dimensions of book reading activities, rather than seeing them as merely individual activities.

3) To develop the reading-related awareness of children and adolescents, children should be enabled to encounter literary activities from early childhood on. It is important that the literary activities are appropriate for the development of children and adolescents and entertaining for them, too. 
4) Reading is the most effective way to learn. Thus, children's reading experiences must be initiated at early ages.

5) Just as children need to read books or have books read to them, adolescents and adults need reading, too. God reading habits must always be supported. Doing so is crucial for acquiring a variety of cognitive skills, establishing social interaction with other individuals, and finding new solutions to problems.

\subsection{Take Action}

To develop interactive reading habits among adolescents and their siblings, the following steps needs to be taken:

1) Teachers should consider the social and interactive dimensions of book reading activities, rather than seeing them as merely individual activities;

2) To develop the reading awareness of children and adolescents, children should be exposed to encounter literary activities at early ages. It is important that the literary activities are appropriate for the children and adolescents' development and entertaining for them, too;

3) To obtain books to read, most adolescents choose to buy them. Therefore, it is important to make plans to create libraries with improved services in schools;

4) Teachers should perform activities such as preparing lists of popular books and displaying them, announcing new book releases and promoting books;

5) Students need to have homework on reading and creating tales that they can share with their siblings;

6) Adolescents should be enabled to organize library camps and reading parties with their siblings and to hold such activities;

7) The required substructure should be provided to allow adolescents to perform activities such as hunting tales and adapting adult novels for kids.

\subsection{More to Explore}

1) According to some of similar researches; none of the Hacettepe University students have a daily reading habit, and almost half of them read less than every few days. Bilkent University students usually do have a daily reading habit (Yilmaz, Kose, \& Korkut, 2009).

2) Similarly according to a survey of seniors in the departments of Physical Education and Sports of 40 universities (46 departments in total) in 2001, students do not read. The reasons for this are the facts that television is attractive, books are expensive, students have a heavy school schedule, do not like reading, and there is no guidance. This study shows that when students have their own rooms, it positively affects the frequency of their reading (Semerci, 2002).

3) Hizlan (2004) and Hughes \& Rodge (2007) complained about families' attitudes towards reading. They indicated the most important reason for failing to develop good reading habits is that educators and families focus exclusively on textbooks as a reading activity, and when adolescents read a novel, they tell them to read their textbooks instead.

\section{References}

Alleyne, C., Smith, K., Landry, S. H., \& Swank, P. R. (2005). The İnfluence of Decreased Parental Resources on the Efficacy of a responsive Parenting İntervention. Journal of Consulting and Clinical, 73, 711-720. http://dx.doi.org/10.1037/0022-006X.73.4.711

Balci, A., Uyar, Y., \& Buyukikiz, K. K. (2012). The Examination of Reading Habits, Frequency to Use Library and Attitudes towards Reading of 6th Grade Primary School Students. International Periodical for the Languages, Literature and History of Turkish or Turkic, 7, 965-985. http://dx.doi.org/10.7827/turkishstudies.3795

Bamberger, R. (1990). Developing the Reading Habituation (Tra: B. Çapar). Ankara: Ministry of Culture Publishing.

Barber, B., Olsen, J., \& Shagle, S. (1994). Associations between Parental Psychological Control and Behavioral Control and Youth İnternalized and Externalized Behaviors. Child Development, 65, 120-136. http://dx.doi.org/10.2307/1131309

Bartle-Haring, S., Brucker, P., \& Hock, E. (2002). The Impact of Parental Separation Anxiety on Identity Development in Late Adolescence and Early Adulthood. Journal of Adolescent Research, 17, 439-450.

http://dx.doi.org/10.1177/0743558402175001

Bowlby, J. (1969). Attachment and Loss: Vol. 1. Attachment. New York: Basic Books. 
Brody, G. H. (1998). Sibling Relationship Quality. It’s Causes and Consequences. Annual Review Psychology, 49, 1-24. http://dx.doi.org/10.1146/annurev.psych.49.1.1

Brody, G. H., Stoneman, Z., \& McCoy, J. K. (1994). Forecasting Sibling Relationships in Early Adolescence from Child Temperaments and Family Processes in Middle Childhood. Child Development, 65, 771-784. http://dx.doi.org/10.2307/1131417

Bryant, B. K., \& Crockenberg, S. (1980). Correlates and Dimensions of Prosocial Behavior: A Study of Female Siblings with Their Mothers. Child Development, 51, 529-544. http://dx.doi.org/10.2307/1129288

Buyukkavas, Kuran, S., \& ve Ersozlu, Z. N. (2009). Class Teachers’ Opinion about Child Literature. Journal of Yuzuncu Yil University Faculty of Education, 1, 1-17.

Calkins, L. M. (2001). The Art of Teaching Reading. New York: Longman.

Christ, G. H., Seigel, K., \& Christ, A. E. (2003). Adolescent Grief: It Never Really Hit Me. Until It Actually Happened. Journal of the American Academy of Child \& Adolescent Psychiatry, 42, 441-450.

Cole, A. (1996). Qualitative Aspects of the Sibling Relationships: A Cross-Sectional Analysis of the Early Adolescent Years. Dissertation Abstracts International, 57, 6646.

Crosswhite, J. M., \& Kerpelman, J. (2009). Coercion Theory, Self-Control, and Social Information Processing: Understanding Potential Mediators for How Parents Influence Deviant Behaviors. Deviant Behavior, 30, 611-646. http://dx.doi.org/10.1080/01639620802589806

Criss, M. M., Lee, T. K., Morris, A. S., Cui, L., Boster, C. D., Shreffler, K. M., \& Silk, J. (2013). Link between Monitoring Behavior and Adolescent Adjustment: An Analysis of Direct and Indirect Effects. Journal of Child Family Studies, 60, 3044.

Clark, C., \& Rumbold, K. (2006). Reading for Pleasure: A Research Overview. London: National Literacy Trust.

Dalton, T. A., \& Krout, R. E. (2005). Development of the Grief Process Scale through Music Therapy Songwriting with Bereaved Adolescents. Arts in Psychotherapy, 32, 131-143. http://dx.doi.org/10.1016/j.aip.2005.02.002

Degirmencioglu, S. M., Urber, K. A., Tolson, J. M., \& Richard, P. (1998). Adolescent Friendship Networks: Continuity and Change over the School Years. Merrill-Palmer Quarterly, 44, 313-337.

Dekovic, M., Janssens, J. M., \& As, N. M. C. (2003). Parental Predictors of Antisocial Behavior in Adolescence. Family Process Journal, 42, 223-235. http://dx.doi.org/10.1111/j.1545-5300.2003.42203.x

Dishion, T. J., \& Patterson, G. (2006). The Development and Ecology of Antisocial Behavior. In D. Cicchetti, \& D. J. Cohen (Eds.), Developmental Psychopathology, Risk, Disorder, and Adaptation (Vol. 3, pp. 503-541). New York: John Wiley \& Sons.

Elliker, M. J. (2005). The Importance of Genderroles in Childrens' Literature. Unpublished Master's Thesis, University Park, PA: Pennsylvania State University.

Ersozlu, Z., \& Kuran, S. (2009). The Class Teacher's Opinions about Child Literature. Yuzuncu Yil University Faculty of Education Journal, 6, 1-17.

Gomleksiz, M. N. (2004). A Scales Validity and Reliability about Reading Book Habituation. The Journal of Firat University Social Sciences, 14, 185-195.

Gonen, M., Oncu, E., \& Isitan, S. (2004). Analysing of Primary 5., 6. ve 7. Class of Students’ Reading Habituation. Journal of National Education, 164, 7-35.

Gray, B. Q. (1975). Dialect İnterference in Writing: A Tripartite Analysis. Journal of Basic Writing, 1, 14-22.

Gungor, E. (2009). The Relation between the Fifth Class of Primary Students' Reading Book Habituation and Students' Academic Success on Turkishlesson. Master's Thesis, Adana: Social Sciences Institute, Çukurova University.

Gurcan, H. İ. (1999). A Model Suggestion Based on Turkey Conditions in View of Reading Habituation and Book Publishing Problems about Culture Linter Communication and Technology. No. 1113, Eskisehir: T.C. Anadolu University Publishing.

Hizlan, D. (2004). Reading and Teaching Culture. Reading Culture and Convention of Applying Problems at Schools (pp. 54). Ankara: Management of Governments’ Book.

Hoskins, D. H. (2014). Consequences of Parenting on Adolescent Outcomes. Journal of Societies, 4, 506-531. http://dx.doi.org/10.3390/soc4030506

Hughes, H. S., \& Rodge, P. (2007). The Leisure Reading Habits of Urban Adolescents, İnternational Reading Association. Journal of Adolescent \& Adult Literacy, 51, 22-33. http://dx.doi.org/10.1598/JAAL.51.1.3

Hunt, P. (1996). Understanding Children's Literature. McGillis, Key Essays from the International Companion Encyclopedia of Children's Literature, New York: Routledge.

Huck, C., Kiefer, B., Hepler, S., \& Hickman, J. (2003). Children's Literature in the Elementary School (8th ed.). Columbus, OH: McGraw-Hill. 
Joosen, V., \& Vloeberghs, K. (2006). Changing Concepts of Childhood and Children's Literature (pp. 1-229). Newcastle: Cambridge Scholars Press.

Layne, C. M., Pynoos, R. S., Saltzman, W. R., Arslanagic, B., Black, M., Savjak, N. et al. (2001). Truama/Grief-Focused Group Psychotherapy: School-Based Postwar Intervention with Traumatized Bosnian Adolescents. Group Dynamics: Theory, Research and Practice, 5, 277-290. http://dx.doi.org/10.1037/1089-2699.5.4.277

Maltepe, S. (2009). The Turkish Language Teachers' Qualifications of Election to Child Literature Products. Journal of Balikesir University Social Sciences Institute, 12, 398-412.

Mendoza, J., \& Reese, D. (2001). Examining Multicultural Picture Books for the Early Childhood Classroom: Possibilities and Pitfalls. Early Childhood Research \& Practice, 3, 1-38.

Newbery, J. (1765). The History of Little Goody Two Shoes (5th ed., pp. 100-160). London: Newbery and Carnan.

Odabas, H., Odabas, Y., \& Polat, C. (2008). The Reading Habituation of University Students World of İnformation, Ankara University Sample. Information World, 9, 431-465.

Oliva, A., \& Arranz, E. (2005). Sibling Relationships during Adolescence. Europen Journal of Developmental Psychology, 2 , 253-270. http://dx.doi.org/10.1080/17405620544000002

Ozkan, B., \& ve Sahbaz, N. K. (2011). Turkish Teacher Candidates' Opinions about Functionality of Fieldlessons. The Journal of Sakarya University Faculty of Education, 1, 32-43.

Rotheram-Borus, M. J., Stein, J. A., \& Lin, Y. (2001). Impact of Parental Death and an Intervention on the Adjustment of Adolescents Whose Parents Have HIV/AIDS. Journal of Consulting and Clinical Psychology, 69, 763-773. http://dx.doi.org/10.1037/0022-006X.69.5.763

Sandler, I. N., Ayers, T. S., Wolchik, S. A., Tein, J. Y., Kwok, O. M., Haine, R. A. et al. (2003). The Family Bereavement Program: Efficacy Evaluation of a Theory-Based Prevention Program for Parentally-Bereaved Children and Adolescents. Journal of Consulting and Clinical Psychology, 71, 587-600. http://dx.doi.org/10.1037/0022-006X.71.3.587

Santora, L. A. (2013). Assesing Children's Literature. Articleoriginally Appeared in Our children, Anti-Defamation League, 3.

Seginer, R. (1998). Adolescents’ Perceptions of Relationships with Older Sibling in the Context of Other Close Relationships. Journal of Research on Adolescence, 8, 287-308.

Semerci, Ç. (2002). The Reading Habituation among the Students’ of Physical Education and Sport at Turkish Universities. Journal of Education and Science, 27, 36-43.

Sever, S. (2004). Child and Literature (pp. 9). Ankara: Kok Publishing.

Sirin, M. R. (2007). The Critical View at Child Literature. Ankara: Kok Publishing.

Stahlschmidt, A. D. (1981). A Study of the Recreational Book Reading Habits of Selected Fifth Grade Children. Dissertation Abstract International, 42, 45-52.

Stanovich, K. E. (2000). Progress in Undertanding Reading: Scientific Foundations and New Frontiers. New York: Guilford Press.

Stocker, C., \& Dunn, J. (1994). Sibling Relationships in Childhood and Adolescence. In R. Plomim (Ed.), Nature and Nurture during Middle Childhood (pp. 205-242). Malden, MA: Blackwell Publishers.

Tucker, C., Barber, B., \& Eccles, J. (1997). Advice about Life Plans and Personal Problems in Late Adolescent Sibling Relationships. Journal of Youth and Adolescence, 26, 63-76. http://dx.doi.org/10.1023/A:1024540228946

Ucgun, D. (2010). The Candidate of Classteachers’ Attitude about Child Literature Lesson and Child Literature Products. Proceedings of the 9th National Symposium about Class Teachers’ Education, Elazig, 20-22 May 2010, 472-477.

Ungan, U. (2008). Culturel Substructure of Our Reading Habituation. Gaziantep University Social Sciences Journal, 7, 218228.

Yeh, H., \& Lempers, J. D. (2004). Perceived Sibling Relationships and Adolescent Development. Journal of Youth and Adolescence, 33, 133-147. http://dx.doi.org/10.1023/B:JOYO.0000013425.86424.0f

Yilmaz, B., Kose, E., \& Korkut, S. (2009). The Study about Students’ Reading Habituation Which Training at Hacettepe University and Bilkent University. Turkish Librarian Ship Central Articles, 23, 22-51. 